\title{
NOTES
}

\section{STATE "COPYRIGHT" PROTECTION FOR PERFORMERS: THE FIRST AMENDMENT QUESTION}

In Zacchini v. Scripps-Howard Broadcasting Co., ${ }^{1}$ the Supreme Court held that a television station does not enjoy any first amendment privilege to report in its entirety a "human cannonball" act recognized as professional property under state law. The decision is an important step in the developing law governing the conflict between the media's right to report "newsworthy" information and the right of entertainers to protect their public performances from unauthorized media dissemination.

The case involved a "human cannonball" act in which Hugo Zacchini, the human cannonball, was shot from a cannon into a net 200 feet away. While Zacchinj was performing his act at an Ohio county fair, a television news reporter videotaped the act over Zacchini's express objection. The film of Zacchini's entire fifteen-second performance, accompanied by favorable commentary, ${ }^{2}$ was broadcast that evening in a segment of a regularly scheduled Cleveland news program. Zacchini sued the television station for misappropriation of his professional property.

Recognizing that Ohio law gave Zacchini an enforceable property interest in his act in the form of a "right of publicity,"3 the Ohio

THE FOLLOWING CITATIONS WILL BE USED IN THIS NOTE:

M. Nimmer, Nimmer on Copyright (1978) [hereinafter cited as M. NimmER];

Goldstein, Copyright and the First Amendment, 70 Colum. L. Rev. 983 (1970) [hereinafter cited as Goldstein].

1. 433 U.S. 562 (1977).

2. The following script was read by the news reporter while Zacchini's filmed act was shown:

This . . . now . . . is the story of a true spectator sport . . the sport of human cannonballing . . . in fact, the great Zacchini is about the only human cannonball around, these days . . . just happens that, where he is, is the Great Geauga County Fair, in Burton . . . and believe me, although it's not a long act, it's a thriller. . . and you really need to see it in person . . . to appreciate it. ...

433 U.S. at 564 n.1 (emphasis in original).

3. See note 65 infra and text accompanying notes $65-80$ infra. 
Supreme Court found that Zacchini was entitled to "exclusive control over the publicity given to his performances." 4 Nevertheless, the Ohio court held that the television station's infringement of Zacchini's right of publicity was constitutionally privileged. Relying in part on the Supreme Court's decision in Time, Inc. v. Hill, ${ }^{5}$ the court held that the television station's broadcast was not actionable because it involved a report of a newsworthy event of legitimate public interest. ${ }^{6}$ In articulating the nature of the concept of "newsworthiness," the court stated:

The proper standard must necessarily be whether the matters reported were of public interest, and if so, the press will be liable for appropriation of a performer's right of publicity only if its actual intent was not to report the performance, but, rather, to appropriate the performance for some other private use, or if the actual intent was to injure the performer. ${ }^{7}$

After granting certiorari on the ground that the state court's recognition of a news privilege might have been "compelled" by a misinterpretation of its first amendment cases, the Supreme Court reversed in a $5-4$ decision. ${ }^{8}$ The Court's opinion, written by Justice White, goes to great lengths to distinguish the Zacchini case from the long line of Supreme Court decisions that imposed first amendment limitations on state law actions for defamation and invasion of privacy. In making this distinction, the Court in essence held that the first amendment permits, under the rubric of newsworthiness, a greater intrusion into individual rights in reputation and privacy than into individual rights in intellectual property. This Note will explore this double standard and will argue that, while the scope of the media's right to disseminate newsworthy performances should not be coextensive with the privileges enjoyed under the defamation and privacy cases, the first amendment requires a limited media privilege to disseminate newsworthy reports involving a performer's act. It will be argued further that the Court's reliance on the fact that Zacchini's entire act was broadcast produced a standard that is, even within the bounds of intellectual property law, a mechanical and poorly conceived legal test.

4. Zacchini v. Scripps-Howard Broadcasting Co., 47 Ohio St. 2d 224, 232, 351 N.E.2d 454, 460 (1976).

5. 385 U.S. 374 (1967). See text accompanying notes $26-28$ infra.

6. 47 Ohio St. $2 d$ at 235,351 N.E.2d at 461 .

7. $I d$.

8. 433 U.S. 562 (1977). Justice Powell filed a dissenting opinion in which Justices Brennan and Marshall joined. In a separate dissenting opinion, Justice Stevens argued that the Ohio court's grounds of decision were sufficiently ambiguous to require remand to determine whether the decision rested on independent and adequate state grounds. Id. at 582-83. See generally Note, Supreme Court Treatment of State Court Cases Exhibiting Ambiguous Grounds of Decision, 62 Colum. L. Rev. 822 (1962). 
I. Intellectual Property vs. Reputation and Privacy: The COURT'S DiCHOTOMY

At the threshold of the Court's analysis in Zacchini there is a crucial effort to distinguish the first amendment considerations in intellectual property law from the first amendment limitations on the law of defamation and invasion of privacy. Characterizing the Ohio Supreme Court's opinion as relying "heavily" on Hill, the Court stated that the right of privacy at stake in Hill was analytically distinct from the publicity right afforded by Ohio to Hugo Zacchini. The Court in Hill, Justice White asserted, was aware that it was adjudicating a falselight privacy case and not the "discrete kind of 'appropriation' case"10 at issue in Zacchini. Therefore, he reasoned, the Hill standard was inapplicable to Zacchini because

[t]he Constitution no more prevents a State from requiring [the television station] to compensate [Zacchini] for broadcasting his act on television than it would privilege [the television station] to film and broadcast a copyrighted dramatic work without liability to the copyright owner, ... or to film and broadcast a prize fight, . . . or a baseball game ...."11

The celebrated line of defamation cases emanating from New York Times Co. v. Sullivan ${ }^{12}$-Rosenbloom v. Metromedia, Inc., ${ }^{13}$ Gertz v. Robert Welch, Inc. ${ }^{14}$ and Time, Inc. v. Firestone ${ }^{15}$-were similarly treated as a distinct and essentially unrelated line of precedent: "These cases . . . emphasize the protection extended to the press by the First Amendment in defamation cases, particularly when suit is brought by a public official or a public figure. None of them involve an alleged appropriation by the press of a right of publicity existing under state law."16

It is this crucial distinction between the line of precedent arising from New York Times and Hill and the precedent associated with intellectual property cases that provided the Court with an analytical basis for its reversal of the Ohio court's decision. If Zacchini had been de-

9. 433 U.S. at $566-67,570$.

10. Id. at 571-72. The Court found it "abundantly clear that Time, Inc. v. Hill did not involve a performer, a person with a name having commercial value, or any claim to a 'right of publicity." Id. at 572.

11. Id. at 575.

12. 376 U.S. 254 (1964). See notes 20-23 infra and accompanying text.

13. 403 U.S. 29 (1971). See notes $34-37$ infra and accompanying text.

14. 418 U.S. 323 (1974). See notes $41-49$ infra and accompanying text.

15. 424 U.S. 448 (1976). See notes 50-57 infra and accompanying text.

16. 433 U.S. at 574. 
famed by the television station he might have been denied relief under the New York Times standard. ${ }^{17}$ Had he sued for a false-light invasion of privacy the television station would have escaped liability under the Hill standard. ${ }^{18}$ Nevertheless, because he claimed injury not to his reputation or sensibilities but only to his pocketbook, Zacchini prevailed in the Supreme Court. To explore the wisdom of this dual constitutional standard it is necessary to review the history of the concept of "newsworthiness," first as it has fared under the defamation/privacy line of cases and then as a component of intellectual property law.

\section{A. Newsworthiness and the Defamation/Privacy Cases.}

The concept of newsworthiness has been an integral part of the evolution of constitutional limitations on the common law of defamation and privacy. This subsection of the Note will trace the evolution of the newsworthiness doctrine in defamation and privacy law from its inception in New York to its culmination in Rosenbloom. It will be shown that the development of the newsworthiness analysis-which focused the first amendment inquiry on the nature and subject matter of a publication-provided courts with a doctrinally and pragmatically sound method of distinguishing protected from unprotected speech. The Court's subsequent retreat from Rosenbloom in Gertz and Firestone will then be critically examined. It will be suggested that, rather than eliminating the newsworthiness concept as a first amendment doctrine in defamation law, the Gertz and Firestone decisions merely altered the definition of the term "newsworthiness."

1. Evolution: from New York Times to Rosenbloom. Until 1964, libelous speech was thought to be outside the purview of first

17. In Gertz the Court stated that certain persons who would otherwise be designated private figures may still be deemed public figures "for a limited range of issues." 418 U.S. at 351. Some persons, however, because of their fame or notoriety are public figures "for all purposes and in all contexts." Id. In either case "[t]he New York Times standard defines the level of constitutional protection appropriate to the context of defamation . ..."Id. at 342. Consequently, a public figure may recover for defamation "only on clear and convincing proof that the defamatory falsehood was made with knowledge of its falsity or with reckless disregard for the truth." Id.

Had the television station accompanied its filmed report with false allegations that the human cannonball act was merely an optical illusion, deliberately designed to defraud and mislead the paying public, the damage to Zacchini's professional reputation might have caused a significant decrease in the economic value of his act as well as psychic harm. Nevertheless, in an action for defamation he would have been denied recovery absent proof of knowing or reckless falsity.

18. In Hill the Court stated that " $[t]$ he guarantees for speech and press are not the preserve of political expression or comment upon public affairs . . ." 385 U.S. at 388 . Thus, it held, a person seeking to recover damages for a false-light invasion of privacy is subject to the New York Times burden of proof if the matter reported was of "public interest." Id. at 387-88. See text accompanying notes 26-28 infra. 
amendment protection. ${ }^{19}$ Then, in New York Times, a unanimous Court held that libelous speech concerning the official conduct of public officials is privileged by the first amendment unless the libel constitutes a knowing or reckless falsehood. ${ }^{20}$ This protection of some admittedly false speech was required by the first amendment, the Court reasoned, to ensure the free discussion of public issues essential to the proper functioning of an enlightened democracy. ${ }^{21}$ In adopting as a constitutional principle the Madisonian view that "[t]he right of free public discussion of the stewardship of public officials . . . [is] a fundamental principle of the American form of government," York Times Court effectively elevated the public interest in matters relevant to self-government to a position of central importance in first amendment theory. ${ }^{23}$

19. At common law a defamation plaintiff-whether private citizen or government official-was entitled to recover damages unless the defendant could prove that the speech was either truthful or protected by one of a limited number of common law privileges. Damages were presumed in certain cases, and the publisher's motives generally were not examined. Absent proof of truth or privilege, defendants were held strictly liable, regardless of the subject matter of the libelous speech. "This [restriction on speech] was assumed to be of no first amendment concern, because the Court had said repeatedly in dicta that libelous words were not protected by the Constitution." Anderson, Libel and Press Self-Censorship, 53 TexAs L. Rev. 422, 422-23 (1975); see Note, Defamation, Privacy and the First Amendment, 1976 Duke L.J. 1016, 1020-21.

20. The plaintiff was an elected official of the city of Montgomery, Alabama, who had won a jury verdict in state court after claiming that he had been libeled by certain statements appearing in a political advertisement in the New York Times. The text of the advertisement had alleged, inter alia, that the Montgomery police had violated the civil rights of black students. While conceding that certain of the statements contained in the advertisement were erroneous, 376 U.S. at 258 , the Court held that

[t] he constitutional guarantees [of free speech] require . . . a federal rule that prohibits a public official from recovering damages for a defamatory falsehood relating to his official conduct unless he proves that the statement was made with "actual malice"-that is, with knowledge that it was false or with reckless disregard of whether it was false or not.

Id. at $279-80$.

21. A rule compelling the critic of official conduct to guarantee the truth of all his factual assertions-and to do so on pain of libel judgments virtually unlimited in amount-leads to ... "self-censorship." Allowance of the defense of truth, with the burden of proving it on the defendant, does not mean that only false speech will be deterred. . . . Under such a rule, would-be critics of official conduct may be deterred from voicing their criticism, even though it is believed to be true and even though it is in fact true, because of doubt whether it can be proved in court or fear of the expense of having to do so. They tend to make only statements which "steer far wider of the unlawful zone." The rule thus dampens the vigor and limits the variety of public debate.

Id. at 279 (citation omitted).

22. Id. at 275 .

23. In an article exploring the historical and philosophical bases for the New York Times decision, Justice Brennan described the case as one that "presented a classic example of an activity that Dr. Meiklejohn called an activity of 'governing importance' within the powers reserved to the people and made invulnerable to sanctions imposed by their agency-governments." Brennan, The Supreme Court and the Meiklejohn Interpretation of the First Amendment, 79 HARv. L. REv. 1, 14 (1965). Because the case involved an activity of "governing importance"-the criticism of the 
For a time it remained uncertain whether the New York Times privilege was to be broadly applied or confined to the narrow class of cases that involved political or seditious libel. ${ }^{24}$ One commentator who quickly perceived the potential breadth of the principle underlying the New York Times decision observed with some prescience that "the invitation [for the Court] to follow a dialectic progression from public official to government policy to public policy to matters in the public domain, like art, seems ... to be overwhelming."25 Within three years of the decision the Court, in Hill, indicated that it would indeed accept the "invitation" so to expand its new first amendment doctrine.

The Hill case was a statutory right of privacy action involving the publication of nondefamatory falsehoods concerning private individuals. $^{26}$ The false statements had appeared in a Life magazine report on the opening of a new play that had been inspired, in part, by an ordeal suffered by the Hill family. Sustaining the publisher's claim of a first amendment privilege, the Supreme Court held that the first amendment permitted recovery for nondefamatory falsehoods concerning matters of public or general concern only upon proof of knowing or reckless falsity. The New York Times privilege applied equally to a report of the opening of a play, the Court explained, because "[t]he guarantees for speech and press are not the [exclusive] preserve of political expression or comment upon public affairs . . .".27 Thus, at least within the context of the right of privacy, the Court effectively enlarged the perimeters of constitutionally protected speech to include reports of all newsworthy matters. ${ }^{28}$

official conduct of a government official-the Court, Justice Brennan explained, relied on none of the tests traditionally applied in determining the validity of attempts by the government to regulate speech. "Instead, the Court examined history to discern the central meaning of the first amendment, and concluded that that meaning was revealed in Madison's statement 'that the censorial power is in the people over the Government, and not in the Government over the people." Id. at 15 (quoting 4 ANNALS OF CONGRess 934 (1794)).

24. See, e.g., Brennan, supra note 23, at 19; Kalven, The New York Times Case: $A$ Note on "The Central Meaning of the First Amendment," 1964 Supreme Court Rev. 191, 221.

25. Kalven, supra note 24, at 221.

26. Dean Prosser identified four distinct torts, each of which is actionable as an invasion of the right of privacy. The "false-light" branch of the tort recognizes that a person's sensibilities may be injured by nondefamatory falsehoods that place him in a "false light in the public eye." Although reputational injury need not be shown, the falsehoods generally must be of a kind that the average, reasonable person in similar circumstances would find objectionable. W. Prosser, The LAw OF TORTs $\S 117$, at 812-14 (4th ed. 1971). The Zacchini Court adopted Dean Prosser's terminology in characterizing Hill as a false-light case. 433 U.S. at 571.

27. 385 U.S. at 388.

28. See Kalven, The Reasonable Man and the First Amendment: Hill, Butts, and Walker, 1967 Supreme Court Rev. 267, 282-83. Professor Kalven characterized New York Times as a "silent partner" in the Hill decision:

What it did was to illuminate for the Court the possibilities of censorship, by individual 
The Court did not immediately adopt the Hill newsworthiness rationale as an express constitutional limitation on nonpolitical libel; instead, the doctrine was incorporated in a series of cases. Having established in New York Times that public discussion of the official conduct of public officials is privileged, the Court went on in Curtis Publishing Company v. Butts ${ }^{29}$ to articulate a similar privilege for the defamation of persons classified as "public figures." 30

The Butts decision did not expressly invoke the Hill rationale; rather, its extension of the applicability of the New York Times privilege was premised on the public's interest in the conduct of nonofficial persons who are "intimately involved in the resolution of important public questions" or famous enough to "shape events in areas of concern to society at large." 31 Nonetheless, the influence of the Hill newsworthiness principle can be perceived in the broad definition of "public figure" subscribed to by five members of the Court. ${ }^{32}$ Rejecting the view that public figure status should be predicated solely upon an individual's voluntary involvement in public matters prior to and independent of the event giving rise to the libel, ${ }^{33}$ the majority adopted a definition that encompassed previously anonymous persons involuntarily in the public eye because of current involvement in matters of public interest. It is clear, therefore, that a majority of the Court in the public figure libel cases viewed the newsworthiness of the subject matter of a libel as the line of demarcation dividing protected from unprotected speech.

The newsworthiness rationale implicit in the Butts definition of

libel actions, of criticism of government operation and policy. It thus set the perspective the Court took toward the events in Hill. The individual tort action, albeit in privacy, carries a comparable threat of censorship over valued, albeit less urgently valued, public speech. Thus although Hill with its mild entertainment news value was on its face worlds removed from New York Times on its grim facts about Negro protests, the two cases were seen to fall within a common sphere-speech affecting individuals that is of public interest.

Id. 283.

29. 388 U.S. 130 (1967). The Butts case was reported together with Associated Press v. Walker.

30. Butts was the athletic director at the University of Georgia. In an article published in the Saturday Evening Post Butts was falsely accused of fixing a football game by revealing information about the Georgia team's plays to the coach of the opposing team. The Supreme Court upheld Butts' libel judgment. 388 U.S. at 161. Walker, the respondent in the companion case, see note 29 supra, was a retired army general. An Associated Press report had falsely accused him of leading a violent demonstration aimed at preventing the enrollment of a black student at the University of Mississippi. The Court reversed Walker's libel judgment Id. at 161-62.

31. Id. at 163-64 (Warren, C.J., concurring).

32. Justices Black, Brennan, Douglas and Marshall and Chief Justice Warren concurred in the definition.

33. This narrower definition of "public figure" was subscribed to by Justices Harlan, Clark, Fortas and Stewart. 388 U.S. at 154-55 (opinion of Harlan, J.). 
public figures eventually was made the explicit basis for the extension of the New York Times standard to private defamation plaintiffs in Rosenbloom v. Metromedia, Inc. ${ }^{34}$ Justice Brennan, speaking for a plurality of the Court, reasoned that the public interest-the same principle that had compelled the New York Times decision-required the abandonment of the public figure/private figure distinction in libel. ${ }^{35}$ Instead, he argued, the constitutional inquiry should focus on the nature of the subject matter giving rise to the defamation. This change of focus was mandated by the first amendment because "[t]he public's primary interest is in the event; the public focus is on the conduct of the participant and the content, effect, and significance of the conduct, not the participant's prior anonymity or notoriety."36 For this reason, the plurality held, the New York Times privilege applied as well to defamatory speech concerning private individuals, provided the subject matter of the libel was of public or general concern. ${ }^{37}$

The Rosenbloom plurality recognized that "[i]f a matter is a subject of public or general interest, it cannot suddenly become less so merely because a private individual is involved . . .."38 The recognition of this fact, and the extension of the New York Times privilege to private figures, can be viewed as logically necessary steps in the evolution of a first amendment doctrine premised from its inception on the value of promoting public debate on a wide range of issues. ${ }^{39}$ In $\mathrm{New}$ York Times, the Court held for the first time that the public interest in matters pertaining to self-government mandates constitutional protection for speech constituting political and seditious libel. In Butts, the Court reasoned that a constitutional distinction between public officials and public figures had "no basis in law, logic, or First Amendment policy" if adequate protection were to be given to "the rights of the press and public to inform and be informed on matters of legitimate

34. 403 U.S. 29 (1971). Rosenbloom, a magazine distributor, had been arrested for selling allegedly obscene material. After his inventory of nudist magazines was seized by the police Rosenbloom sought injunctive relief. A local broadcaster reporting on the injunctive action characterized the confiscated magazines as "obscene" and implied that Rosenbloom was a peddler of "girlie-books." Id. at 32-35.

35. Chief Justice Burger and Justice Blackmun joined in Justice Brennan's opinion. Justice Black concurred in the result on the ground that the press should be absolutely immune to liability for defamation, id. at 57, and Justice White concurred on the narrower ground that the press should be privileged to report the official conduct of public servants. Id. at 62 . Justice Douglas did not participate in the decision.

36. Id. at 43 (footnote omitted).

37. Id.

38. Id.

39. See Anderson, supra note 19, at 445-46. Professor Anderson points out that this logical basis for the New York Times privilege was recognized by the many lower courts that applied the standard to private plaintiffs prior to the Rosenbloom decision. Id. 446 \& n.113. 
interest."40 Finally, the privilege was extended in Rosenbloom to protect, on first amendment public interest grounds, the public discussion of any newsworthy matter, without regard to the fame or anonymity of the person defamed. Thus, what began in New York Times as a principle applicable to a narrowly circumscribed area of speech-public discussion of matters relating to the people's self-governing powers-evolved into a doctrine broad enough to protect the discussion of any matter of public or general interest.

2. Redefining the principle: Gertz and Firestone. In Gertz v. Robert Welch, Inc., ${ }^{41}$ the Court re-examined the doctrinal development that had culminated three years earlier in Rosenbloom. Then, without expressly overruling its earlier decision, five members of the Court disavowed the Rosenbloom newsworthiness rationale by holding that the defamation of private persons is not entitled to the New York Times immunity regardless of the newsworthiness of the published matter.

The Gertz Court's uneasiness with the Rosenbloom plurality's newsworthiness rule was rooted in two concerns. First, the Court feared that adherence to the Rosenbloom standard would leave private citizens unduly vulnerable to libel whenever they were involved in events that were of interest to the public. In the majority's view, the requirement that public figures and officials continue to bear the heavy New York Times burden of proof in libel cases remained justified because, having greater access to the media, public persons can resort to extra-judicial "self-help" means of redressing defamatory falsehoods. ${ }^{42}$ For private persons, however, the sole remedy for the harms of defamation is a judicial one. ${ }^{43}$ Therefore, the Court reasoned, when a private person is defamed the state's greater interest in compensating his

40. 388 U.S. at $163-65$.

41. 418 U.S. 323 (1974). Gertz was a lawyer who represented the family of a man murdered by a Chicago policeman. The defendant published a magazine article alleging that Gertz was a "Communist-fronter" who was involved in a conspiracy to discredit the Chicago police. Gertz sued for libel, winning a jury verdict of fifty thousand dollars. The trial court entered judgment n.o.v. for the publisher on the ground that the New York Times standard applied to private figures involved in public issues. Relying on Rosenbloom, the Seventh Circuit affirmed the judgment of the district court. In an opinion written by Justice Powell, in which Justices Stewart, Marshall, Blackmun and Rehnquist joined, the Court reversed, holding that "so long as they do not impose liability without fault, the States may define for themselves the appropriate standard of liability for a publisher or broadcaster of defamatory falsehood injurious to a private individual." Id. at 347 (footnote omitted).

42. The majority reasoned that "[p]ublic officials and public figures usually enjoy significantly greater access to the channels of effective communication and hence have a more realistic opportunity to counteract false statements than private individuals normally enjoy." Id. at 344 (footnote omitted).

43. $1 d$. 
reputational injury justifies a narrowing of Rosenbloom's blanket protection of newsworthy speech. ${ }^{44}$ The second source of the majority's dissatisfaction with Rosenbloom was its fear that the newsworthiness standard would require the judiciary to assume an inappropriate editorial role in order to determine, on a case-by-case basis, which publications concerned matters of "public or general interest." 45 Attempting to mitigate both of these concerns, the Gert $z$ Court changed the focus of its first amendment inquiry from the newsworthiness of the publication at issue to the status of the person defamed. ${ }^{46}$

In holding that only public figures ${ }^{47}$ and public officials must satisfy the New York Times standard, the Gertz Court purported to repudiate the newsworthiness privilege as a first amendment doctrine in defamation cases. ${ }^{48}$ However, an examination of the Gertz rationale as it was applied in Firestone reveals that elements of the newsworthiness concept have been retained, although in altered form, as an essential component of the Court's first amendment analysis. ${ }^{49}$

The Firestone case involved a Time magazine report concerning the divorce decree of Mary Alice Firestone, a prominent Palm Beach socialite. The divorce proceedings had received extensive news coverage, ${ }^{50}$ some of it at the instigation of Mrs. Firestone, who had held several press conferences during the trial. The defamatory statement at issue was an erroneous report that the plaintiff's husband had been

44. Id. The Court found private plaintiffs to be not only more vulnerable to libel but more deserving of protection as well. In the Court's view, public figures "invite attention and comment." Thus, they "have voluntarily exposed themselves to increased risk of injury from defamatory falsehood [sic] concerning them." Id. at 345. A private figure, however, "has relinquished no part of his interest in the protection of his own good name ... Id. See note 60 infra.

45. 418 U.S. at 346 . The majority "doubt[ed] the wisdom of committing this task to the conscience of judges," id., despite Justice Brennan's insistence that the resolution of such constitutional questions was a traditional judicial function. Id. at 369 (Brennan, J., dissenting).

46. Thus, the Court held, states could permit a private defamation plaintiff to recover under any standard except strict liability in cases where the defamatory potential of the publication was apparent. Id, at 347-48.

47. The Gertz Court's definition of a public figure is quoted in the text accompanying note 52 infra.

48. The Court found that a standard that required courts to privilege the discussion of all issues of public or general interest resulted in too "thin a line between the drastic alternatives of the New York Times privilege and the common law of strict liability for defamatory errors." 418 U.S. at 346.

49. See text accompanying notes $52-62$ infra. For a thoughtful pre-Firestone analysis of Gertz's impact on the issue-oriented New York Times doctrine see Brosnahan, From Times v. Sullivan to Gertz v. Welch: Ten Years of Balancing Libel Law and the First Amendment, 26 HASTINGS L.J. 777 (1975).

50. "The 17-month trial and related events attracted national news coverage, and elicited no fewer than 43 articles in the Miami Herald and 45 articles in the Palm Beach Post and Palm Beach Times." 424 U.S. at 485 (Marshall, J., dissenting). 
granted the divorce on the ground of adultery. ${ }^{51}$

To determine whether the New York Times standard applied, the Court first had to decide whether Mrs. Firestone was a public figure. The Gertz opinion had posited two bases for such a determination:

In some instances an individual may achieve such pervasive fame or notoriety that he becomes a public figure for all purposes and in all contexts. More commonly, an individual voluntarily injects himself or is drawn into a particular public controversy and thereby becomes a public figure for a limited range of issues. In either case such persons assume special prominence in the resolution of public questions. ${ }^{52}$

Applying the first criterion, the Court determined that, despite her prominence in the Palm Beach community, Mrs. Firestone was neither famous nor notorious enough to be deemed a public figure for all purposes. ${ }^{53}$ Since there was no question of the extent of Mrs. Firestone's involvement in the reported event, ${ }^{54}$ the Court attempted to determine whether the event itself was a "public question."5s In making this determination the Court necessarily assumed the task of evaluating the public's first amendment interest in receiving news of the Firestone divorce. Only after finding that news coverage of the divorce "would add almost nothing toward advancing the uninhibited debate on public issues thought to provide principal support for the decision in $\mathrm{New}$ York Times" 56 was the Court able to determine that the defendant was

5I. Id. at 450.

52. 418 U.S. at 351.

53. The basis for this finding was that "[r]espondent did not assume any role of especial prominence in the affairs of society, other than perhaps Palm Beach society . . ." 424 U.S. at 453. In Gertz, however, the Court's analysis of the plaintiff's status implied that a person's fame or notoriety in his community would properly support a finding that he was a public figure. In that case the Court declined to designate Gertz as a public figure for all purposes because "he had achieved no general fame or notoriety in the community. None of the prospective jurors called at the trial had ever heard of [Gertz] prior to [the] litigation, and respondent offered no proof that this response was atypical of the local population." 418 U.S. at $351-52$ (emphasis added). In Firestone, however, the record showed that the plaintiff had subscribed to a press-clipping service prior to bringing suit for divorce. This evidenced to Justice Marshall that prior to and independent of the event giving rise to libel Mrs. Firestone had deliberately sought and achieved sufficient local prominence to justify the media's acting on the assumption that she was a public figure. 424 U.S. at 486-87 (Marshall, J., dissenting).

54. Justice Marshall noted in dissent that Mrs. Firestone had held a number of press conferences during the course of the divorce trial. 424 U.S. at 487 (Marshall, J., dissenting). It was clear, therefore, that Mrs. Firestone had "engage[d] the public's attention in an attempt to influence its outcome." Gertz, 418 U.S. at 352.

55. See text accompanying note 52 supra. The Gertz Court, eschewing an issue-oriented analysis, did not define the term "public question." Rather, the Gertz public figure designation appears to have been predicated on the assumption that only a plaintiff's conduct would give rise to limited public figure status.

56. 424 U.S. at 457. 


\section{not entitled to the New York Times privilege. ${ }^{57}$}

Both the Gertz rationale and the Firestone analysis reveal that the Court continues to recognize the need in some cases for a first amendment privilege to disseminate reports of newsworthy matters. The surviving news privilege is not, however, coextensive with the privilege enjoyed by the media under Rosenbloom. Rather, the Court's definition of "newsworthiness" after Gertz and Firestone is both broader and narrower than the short-lived Rosenbloom standard. ${ }^{58}$ In place of Rosenbloom's unitary definition, which privileged the publication of all subject matter of public or general concern regardless of who was defamed, the Court has substituted a two-tiered standard that looks to the newsworthiness of persons as well as events.

The first tier of the Gertz standard subsumes a much broader definition of newsworthiness than was intended by the Rosenbloom plurality since an initial determination of public figure status for all purposes now automatically triggers the New York Times standard. ${ }^{59}$ Consequently, the press is privileged to publish false reports of purely private matters, so long as the publications concern public officials or figures and are not knowingly or recklessly false. This sweeping privilege appears to be predicated on the normative notion that public persons, having once "invite[d] attention and comment" 60 by placing themselves in the public eye, are always newsworthy simply by virtue of their status. The second tier of the Gertz standard narrows the definition of newsworthiness, however. As was demonstrated by the Court's analysis in Firestone, even a person who becomes extensively and publicly involved in a well publicized event will retain private status unless the event itself can be characterized as an issue that is of "governing im-

57. In focusing on the nature of the event involved in Firestone the Court thus "resurrect[ed] the precise difficulties that . . Gertz was designed to avoid." Id. at 487 (Marshall, J., dissenting).

58. The Rosenbloom plurality would have privileged all reports of matters that were found to be of "public or general concern." This remains the standard for false-light privacy cases under Hill. See text accompanying notes 26-28 supra.

59. 418 U.S. at $342-43$.

60. Id. at 345 . In a dissenting opinion Justice Brennan pointed to the doctrinal and logical inconsistency of treating public figures as "newsworthy" in all aspects of their lives:

[V]oluntarily or not, we are all "public" men to some degree. Conversely, some aspects of the lives of even the most public men fall outside the area of matters of public or general concern. [Citation omitted.] Thus, the idea that certain "public" figures have voluntarily exposed their entire lives to public inspection, while private individuals have kept theirs carefully shrouded from public view is, at best, a legal fiction. In any event, such a distinction could easily produce the paradoxical result of dampening discussion of issues of public or general concern because they happen to involve private citizens while extending constitutional encouragement to discussion of aspects of the lives of "public figures" that are not in the area of public or general concern.

Id. at 364 (Brennan, J., dissenting) (quoting Rosenbloom, 403 U.S. at 48). 
portance" to the people. ${ }^{61}$ Conversely, Gertz demonstrates that private figure status will nevertheless be enjoyed even when the event in question is undeniably a public issue of "governing importance" if the plaintiff's public involvement in the event is not extensive. ${ }^{62}$ Thus, unless a defamation plaintiff is a public figure for all purposes, the $\mathrm{New}$ York Times privilege will not apply unless two kinds of newsworthiness are present: the relevant event must be newsworthy because it is a "public question," and the plaintiff must be newsworthy because of his extensive and public involvement in the event.

A discussion of the wisdom of the current status of the media's news privilege in defamation law is beyond the scope of this Note. ${ }^{63}$ For present purposes, it is sufficient to recognize that despite the absence of a unitary constitutional standard, the media continue to enjoy some measure of first amendment immunity to publish newsworthy reports that infringe individuals' interests in their reputations. In addition, the Hill newsworthiness standard continues to privilege the media to infringe individuals' privacy interests when disseminating news that is of public or general concern. ${ }^{64}$ Each of these news privileges remains premised on the Court's recognition of the inherent conflict between the first amendment and state laws that permit individuals to suppress speech that is injurious to their reputations and sensibilities. A similar conflict with the first amendment inheres in laws granting exclusive rights in intellectual property.

\section{B. Newsworthiness and Intellectual Property.}

1. The right of publicity and the public interest. Although the Supreme Court recognized the common law right of publicity ${ }^{65}$ for the

61. Meiklejohn's "governing importance" category has been characterized by Justice Brennan as including "the vast range of forms of thought and expression by which the voter might equip himself to exercise a proper judgment in casting his ballot." Brennan, supra note 23, at 13. Thus, "[e]ducation in all its phases, the achievements of philosophy and the sciences, literature and the arts, all fall within the subjects of 'governing importance' that the first amendment absolutely protects from abridgment." Id.

62. The libel at issue in Gertz involved statements alleging that the plaintiff, a lawyer representing persons suing a police officer, was involved in a Communist conspiracy designed to discredit the Chicago police. 418 U.S. at 325-26. Despite the undeniably public nature of the event in question, the Court found that Gertz had not "thrust himself into the vortex of this public issue, nor did he engage the public's attention in an attempt to influence its outcome." Id. at 352.

63. For an excellent criticism of the Court's current approach to defamation law see Christie, Injury to Reputation and the Constitution: Confusion and Conflicting Approaches, $75 \mathrm{MiCH}$. L. REv. 43 (1976).

64. See Cantrell v. Forest City Publishing Co., 419 U.S. 245, 250-51 (1974).

65. Misappropriations of individuals' names, likenesses and personalities have been litigated under various theories, invasion of the right of privacy being the theory most frequently relied upon. See generally Gordon, Right of Property in Name, Likeness, Personality and History, 55 
first time in Zacchini, its opinion does not employ the traditional right of publicity analysis, which recognizes a public interest defense. ${ }^{66}$ One reason for the Court's novel approach is suggested by its recent defamation decisions: it wished to avoid giving additional constitutional stature to the newsworthiness doctrine as a limitation on state tort law. A second reason can be found in the singular facts of the case itself. Zacchini is one of only a few reported cases to involve the infringement of an entire performance, and is the only one of these where the infringement occurred during a news broadcast. ${ }^{67}$

Nw. U.L. Rev. 553 (1960); Nimmer, The Right of Publicity, 19 LAw \& Contemp. PRoB. 203 (1954); Note, The Right of Publicity-Protection for Public Figures and Celebrities, 42 BROOKLYN L. REv. 527 (1976). The term "right of publicity" is used in this Note to refer to any case where a plaintiff has claimed an infringement of his exclusive property right in his name, likeness or aspects of his personality, regardless of the theory relied upon by the plaintiff or the court.

The enforceable property interest of a celebrity in the commercial value of his name and likeness, apart from any privacy right that may be retained, was first expressly identified as the "right of publicity" by Judge Frank of the Second Circuit Court of Appeals. In Haelan Laboratories, Inc. v. Topps Chewing Gum, Inc., 202 F.2d 866 (2d Cir.), cert. denied, 346 U.S. 816 (1953), the grantee of exclusive rights to use a ballplayer's name and picture to advertise chewing gum sued for tortious inducement of breach of contract after the defendant contracted with the same ballplayer to obtain similar rights. The court agreed with the defendant's contention that, under existing privacy law, the plaintiff's exclusive-use contract did not constitute an assignment but merely served to release the plaintiff from potential liability under the New York privacy statute for unauthorized advertising use of the ballplayer's picture. $202 \mathrm{~F} .2 \mathrm{~d}$ at 867 . However, the court found that the ballplayer, like other persons whose names and likenesses are commercially valuable, had an assignable right to the exclusive use of his name and picture that was independent of New York's statutory right of privacy. Id. at 868 . In defining that right Judge Frank stated:

We think that ... a man has a right in the publicity value of his photograph, i.e., the right to grant the exclusive privilege of publishing his picture, and that such a grant may validly be made "in gross," i.e., without an accompanying transfer of a business or of anything else. Whether it is labelled a "property" right is immaterial; for here . . . the tag "property" simply symbolizes the fact that courts enforce a claim which has pecuniary worth.

This right might be called a "right of publicity."

Id. Therefore, the court held that if the defendant had used the ballplayer's photograph with knowledge of the plaintiff's contract, the use was an actionable appropriation. Id. at 869 .

66. See text accompanying notes 70-72, 76-80 infra.

67. Prior to Zacchini media defendants had been held liable in appropriation cases involving commercial broadcasts of filmed and live athletic events. See Ettore v. Philco Television Broadcasting Corp., 229 F.2d 481 (3d Cir.), cert. denied, 351 U.S. 926 (1956); Pittsburgh Athletic Co. v. KQV Broadcasting Co., 24 F. Supp. 490 (W.D. Pa. 1938). However, the Zacchini case appears to be the only reported case in which a media defendant, clearly acting in a noncommercial capacity as a news disseminator, has been sued for appropriation on the basis of an accurate news broadcast.

In the two reported cases involving performance appropriation a newsworthiness privilege was applied. See Man v. Warner Bros., Inc., 317 F. Supp. 50 (S.D.N.Y. 1970); Gautier v. ProFootball, Inc., 304 N.Y. 354, 107 N.E.2d 485 (1952). In Man, the plaintiff, a musician attending the Woodstock Festival, had climbed onto the stage and played "mess call" on his flugelhorn. His 45-second performance was recorded on film by the defendant and subsequently included in a commercially distributed documentary feature film depicting the famous rock music festival. Man sued for appropriation under the New York privacy statute. The district court held that the statute was not intended to provide a cause of action for the appropriation of a professional enter- 
In the more frequently litigated right of publicity cases a celebrity typically claims that an unauthorized commercial use has been made of his name, his photograph or aspects of his personality ${ }^{68}$ The state's sole purpose in providing him with a remedy is to protect the commercial value of these quasi-property interests. ${ }^{69}$ The celebrity's property rights in his name, likeness and personality are not absolute, however. Courts traditionally have held, and commentators agree, that "[w]here use of a person's name, photograph, or likeness is made in the dissemination of news or in a manner required by the public interest, that person should not be able to complain of the infringement of his right of publicity."70

The newsworthiness privilege to infringe an individual's right of publicity necessarily differs from the correlative privilege in defamation and false-light invasion of privacy cases. Because truthful publications cannot, by definition, give rise to liability for defamation or false-light invasions of privacy-regardless of the injurious effect that some truthful speech may have on an individual's reputation or sensibilities-the constitutional question in defamation and privacy cases concerns only the extent to which the first amendment mandates protection for false speech. ${ }^{71}$ In a right of publicity case, however, the plaintiff usually

tainer's public performances; that the film itself, although a commercial undertaking, was a privileged account of a newsworthy event; and that, in any case, an appropriation of a 45-second performance must be considered de minimus. $317 \mathrm{~F}$. Supp. at 53 . In Gautier, a wild-animal trainer had contracted with the owner of a football team to perform his animal act during the halftime of a televised football game. Although his contract expressly provided that the act was not to be televised without the performer's written consent, his entire seven-minute act was included in the commercially sponsored telecast. On appeal of the statutory right of privacy action the New York Court of Appeals found that the appropriation had not been for advertising purposes since the plaintiff "was not connected with the [sponsor's] product either by visual, oral or other reference . . . " 304 N.Y. at 359, 107 N.E.2d at 488. The alternative statutory requirement, a trade purpose, was found to be absent on the ground that the dissemination by the media of newsworthy events, even if done for a profit, was a well-established press exception to the statute. 304 N.Y. at 360,107 N.E.2d at 488 . Finally, the court ruled that in becoming "an actual participant in a public event" and "voluntarily occupying the very center of attraction" the plaintiff had effectively waived his right of privacy. 304 N.Y. at 360, 107 N.E.2d at 489.

68. See, e.g., Uhlaender v. Henricksen, 316 F. Supp. 1277 (D. Minn. 1970) (ballplayers' names and sports statistics used without permission in defendant company's board game); Sharman v. C. Schmidt \& Sons, Inc., 216 F. Supp. 401 (E.D. Pa. 1963) (athlete's picture used to advertise beer); Rosemont Enterprises, Inc. v. Urban Systems, Inc., 72 Misc. 2d 788, 340 N.Y.S.2d 144 (Sup. Ct.), modified, 42 App. Div. 2d 544, 345 N.Y.S.2d 17 (1973) (Howard Hughes' name and biographical data used in defendant's "Howard Hughes Game").

69. See Haelan Laboratories, Inc. v. Topps Chewing Gum, Inc., 202 F.2d 866, 868 (2d Cir.), cert. denied, 346 U.S. 816 (1953).

70. Nimmer, supra note 65, at 216-17. In his seminal article on the right of publicity Professor Nimmer also stated that "the defense of public interest should be no less effective in a publicity action than in a privacy action." Id. at 216. See, e.g., Man v. Warner Bros., Inc., 317 F. Supp. 50 (S.D.N.Y. 1970); Current Audio, Inc. v. RCA Corp., 71 Misc. 2d 831, 337 N.Y.S.2d 949 (Sup. Ct. 1972); Paulsen v. Personality Posters, Inc., 59 Misc. 2d 444, 299 N.Y.S.2d 501 (Sup. Ct. 1968).

71. See text accompanying notes 19-64 supra. 
seeks compensation for damages resulting from a truthful publication. Consequently, courts generally have been willing to limit the right of publicity on public interest grounds in cases presenting a risk of "chilling" the dissemination of truthful speech. ${ }^{72}$

When a public interest defense is asserted in right of publicity cases, courts traditionally look first to the nature of the appropriation. It is well established that the unauthorized use of a person's name or photograph to advertise a product is never privileged. ${ }^{73}$ Similarly, even if there has not been an advertising use, a defendant usually will be liable for a commercial appropriation of an individual's right of publicity. ${ }^{74}$ In such cases, the plaintiff's exclusive property right in his name, likeness or personality has been found to outweigh the slight public interest that might be served by permitting a commercial infringement. $^{75}$ In no case, however, has a state court ruled that the newsworthiness privilege is inapplicable to a noncommercial news infringement.

The right of publicity public interest privilege can be a broad one that "extends far beyond the dissemination of news in the sense of current events and includes . . . even entertainment and amusement, concerning interesting phases of human activity in general."

72. See notes 79-80 infra and text accompanying notes $76-80$ infra.

73. See, e.g., Motschenbacher v. R.J. Reynolds Tobacco Co., 498 F.2d 821 (9th Cir. 1974); Grant v. Esquire, Inc., 367 F. Supp. 876 (S.D.N.Y. 1973). The Grant case involved an unusual factual situation. In 1946, Cary Grant consented to a magazine publisher's use of his photograph in connection with an article on men's fashions. In 1971, an issue of the magazine contained an update of the men's clothing industry. Without obtaining Grant's consent, the publisher used the head from the actor's 1946 picture superimposed on the body of an unidentified model in modern attire. The court held that the news privilege would be applicable unless it was determined, upon further pretrial discovery, that the purported fashion news item was actually a paid advertisement. Id. at 878 .

74. See, e.g., Price v. Hal Roach Studios, Inc., 400 F. Supp. 836 (S.D.N.Y. 1975); Uhlaender v. Henricksen, 316 F. Supp. 1277 (D. Minn. 1970); Rosemont Enterprises, Inc. v. Urban Systems, Inc., 72 Misc. 2d 788, 340 N.Y.S.2d 144 (Sup. Ct. 1973), modified, 42 App. Div. 2d 544, 345 N.Y.S.2d 17 (1973).

75. In Palmer v. Schonhorn Enterprises, Inc., 96 N.J. Super. 72, 232 A.2d 458 (Super. Ct. Ch. Div. 1967), the plaintiffs, well-known professional golfers, were granted injunctive relief when their names and biographical data were used by the defendant in connection with its "Pro-Am Golf Game." Although the defendant had claimed that its use of names and statistics available on public records was privileged, the court held that the appropriation was for commercial rather than for information-dissemination purposes. Id. at 79, $232 \mathrm{~A} .2 \mathrm{~d}$ at 462 . Similarly, the court in Rosemont Enterprises, Inc. v. Urban Systems, Inc., 72 Misc. 2d 788, 340 N.Y.S.2d 144 (Sup. Ct. 1973), modified, 42 App. Div. 2d 544, 345 N.Y.S.2d 17 (1973), found the use of the plaintiff's name and biographical data in connection with the defendant's "Howard Hughes Game" to be a commercial appropriation and not "legitimate to the public interest." 72 Misc. 2d at 790, 340 N.Y.S.2d at $146-47$.

76. Current Audio, Inc. v. RCA Corp., 71 Misc. 2d 831, 836, 337 N.Y.S.2d 949, 955 (Sup. Ct. 1972). 
its breadth, this privilege has enabled courts to excuse even some commercially motivated infringements on the ground that the overriding value of free speech "must supersede [the plaintiff's] private pecuniary considerations."77 For example, the privilege was applied when a performance was used without consent in a commercially produced and distributed documentary film that depicted a public event; ${ }^{78}$ when an unauthorized biography of Howard Hughes was published for the commercial market; ${ }^{79}$ and when a mock political campaign poster featuring a picture of a famous comedian was commercially marketed without his consent. ${ }^{80}$

In the Zacchini case it was undisputed that the television station had used Zacchini's act in the routine dissemination of news. ${ }^{81}$ Thus, in order to justify its decision not to apply the traditional newsworthiness privilege in Zacchini, the Court first had to distinguish the right of publicity in performances from the right of publicity in names, photographs and personalities. To accomplish this the Court found that a state has an interest in compensating performers for infringements of their acts that is not present where it seeks to protect the commercial value of a name, likeness, or personality. This additional state interest-to encourage the production of entertainment-is, the Court reasoned, equivalent to the purpose of the federal copyright statute. ${ }^{82}$

77. Id. at 837,337 N.Y.S.2d at 956.

78. Man v. Warner Bros., Inc., 317 F. Supp. 50 (S.D.N.Y. 1970), discussed at note 67 supra.

79. Rosemont Enterprises, Inc. v. Random House, Inc., 58 Misc. 2d 1, 294 N.Y.S.2d 122 (Sup. Ct. 1968). In Rosemont, the publisher of an unauthorized biography of Howard Hughes was sued by Hughes' company for misappropriation of its " 'sole and exclusive world-wide rights to exploit commercially . . . the name, personality, likeness or the life story or incidents in the life of Hughes' . . . Id. at 2-3, 294 N.Y.S.2d at 125. The court held that

[t]he publication of a biography is clearly outside the ambit of the "commercial use" contemplated by the "right of publicity" and such right can have no application to the publication of factual material which is constitutionally protected. Just as a public figure's "right of privacy" must yield to the public interest so too must the "right of publicity" bow where such conflicts with the free dissemination of thoughts, ideas, newsworthy events, and matters of public interest.

Id. at 6, 294 N.Y.S.2d at 129.

80. Paulsen v. Personality Posters, Inc., 59 Misc. $2 d$ 444, 299 N.Y.S.2d 501 (Sup. Ct. 1968). Paulsen was a famous comedian who, for purposes of political satire, had declared himself a presidential candidate in 1968. Without obtaining Paulsen's consent the defendant produced and sold a "Paulsen for President" poster which featured a picture of the comedian wearing an "Uncle Sam" outfit. When Paulsen sued for infringement of his right of publicity the court found the infringement to be privileged. Although Paulsen claimed that his "political campaign" was only a publicity stunt, the court reasoned that "[w]hen a well-known entertainer enters the presidential ring, tongue in cheek or otherwise, it is clearly newsworthy and of public interest." Id. at 449, 299 N.Y.S.2d at 507.

81. Justice Powell characterized the broadcast of Zacchini's act as "a routine example of the press fulfilling the informing function so vital to our system." 433 U.S. at 580 (Powell, J., dissenting).

82. Id. at 576 . 
Then, focusing the remainder of its analysis on the state's quasi-copyright interest, the Court determined that protecting Zacchini's and other performers' economic interests would, in the long run, promote the public's first amendment interest in access to entertainment. ${ }^{83}$ Conversely, to destroy Zacchini's economic incentive by denying him a remedy for performance infringement would be detrimental to the public interest because it would discourage the production of entertainment. Therefore, the Court concluded, since failure to compensate Zacchini would negate the state's quasi-copyright interest, there should be no first amendment immunity for the unauthorized news broadcast of the performer's entire act.

It may be argued that the Court's analogy between the publicity right in performances and copyright is appropriate. The inadequacy of traditional state law remedies for performance infringements was felt even before the Zacchini case arose. ${ }^{84}$ The need was thought to be particularly acute for some form of copyright protection that would protect against the unauthorized fixation and exploitation of a live performance. ${ }^{85}$ The Zacchini decision clearly recognizes that need. Moreover, in two recent cases, both cited in Zacchini, the Court held that states legitimately may legislate copyright and patent protection for certain forms of creative and intellectual property that remain unprotected by federal legislation. ${ }^{86}$ The Court's recognition in Zacchini that states may provide common law quasi-copyright protection for performers is consistent with those decisions. Nevertheless, the question before the Court in the earlier state cases was whether state legislation dealing with copyrights and patents was preempted by federal laws. ${ }^{87}$ The question in Zacchini, however, was whether the first amendment rendered the infringement of a performance privileged be-

83. See id. at 578 .

84. See generally Lang, Performance and the Right of the Performing Artist, 21 ASCAP CoPYRIGHT L. SYMP. 69 (1974).

85. See id. 72. The term "fixation" is used here to denote the recording, videotaping or filming of a live performance.

86. Kewanee Oil Co. v. Bicron Corp., 416 U.S. 470 (1974); Goldstein v. California, 412 U.S. 546 (1973). Goldstein arose before Congress enacted legislation providing statutory copyright protection for sound recordings. The case involved a challenge to California's "record piracy" statute that made the unauthorized duplication and commercial sale of records and tapes a crime. The Court held that "[u]ntil and unless Congress takes further action with respect to recordings . . . the California statute may be enforced against acts of [record and tape] piracy . . ."412 U.S. at 571. The Kewanee case upheld the validity of Ohio's trade secret law. The Court stated in Kewranee that "t $t$ ]he only limitation on the States is that in regulating the area of patents and copyrights they do not conflict with the operation of the laws in this area passed by Congress ... ." 416 U.S. at 479.

87. No first amendment claim was made in either Goldstein or Kewanee. 
cause of its presentation as news. ${ }^{88}$ "Disclaiming any attempt to do more than decide the narrow case before [it]," 89 the Court answered the question in the negative. An evaluation of the Court's negative answer-the "entire act" rule-requires a brief examination of the concept of "fair use" in copyright law.

2. Fair use: a public interest limitation on absolute copyright protection. While it relied on a copyright analysis, the Zacchini Court failed to note that copyright protection is not absolute. Although statutory copyright confers upon copyright owners an exclusive right to exploit their original works of art or literature, ${ }^{90}$ certain intrusions into this right are excused as "fair uses." 1

The fair use doctrine developed as an equitable rule of reason designed to balance the economic interests of the copyright owner against the public interest in the wide dissemination of information needed for the advancement of knowledge. ${ }^{92}$ Courts and commentators traditionally have found the rationale for the fair use exception in the copyright clause of the Constitution. ${ }^{93}$ The purpose of the statutory protection authorized by the copyright clause is to provide authors with the economic incentive necessary to ensure that a wide variety of original and creative ideas will be made available to the public. This broad range of matter will, in turn, "promote the Progress of Science and useful Arts." $" 94$ If a copyright infringement advances the public interest in such progress without harming the economic interests of the copyright owner, the stated purpose of the copyright clause is served. Thus, under the traditional analysis, such fair infringements must be permitted to best carry out the policy mandated by the copyright

88. The Court granted certiorari in Zacchini "to consider an issue unresolved by [the] Court: whether the First and Fourteenth Amendments immunized respondent from damages for its alleged infringement of petitioner's state-law 'right of publicity.'" 433 U.S. at 565.

89. Id. at 579 (Powell, J., dissenting).

90. See 17 U.S.C. app. $\S 8102(a), 106$ (1976).

91. Id. $\S 107$. Numerous commentators have discussed the fair use doctrine. See, e.g." Goldstein 1011-14; Rosenfield, The Constitutional Dimension of "Fair Use" in Copyright Law, 50 Notre Dame LAw. 790 (1975); Yankwich, What is Fair Use?, 22 ChI. L. Rev. 203 (1954); Note, Copyright Infringement and Fair Use, 40 CINN. L. REv. 534, $541-46$ (1971); Note, Copyright Fair Use: Case Law and Legislation, 1969 DUKE L.J. 73, 86-109.

92. See, e.g., Berlin v. E.C. Publications, Inc., 329 F.2d 541, 544 (2d Cir. 1964).

93. U.S. Const. art. I, § 8, cl. 8. See, e.g., Mazer v. Stein, 347 U.S. 201, 219 (1954); Yankwich, supra note 91, at 213-14.

94. U.S. CoNST. art. I, \& 8, cl. 8. 
clause. $^{95}$

It is generally agreed that "[a]n arbitrary rule [of fair use] conformance to which would be obligatory in all cases, would ill serve the advance of the arts, ideas, and sciences in which the public has an interest."96 Perhaps for this reason, no definitive test of fair use has emerged from the cases; rather, courts review a variety of relevant factors when determining on an ad hoc basis whether a copyright infringement constituted a fair use. ${ }^{97}$ The version of the fair use doctrine that has been codified in the new copyright statute suggests the following nonexclusive list of relevant factors that traditionally have been considered by copyright courts:

(1) the purpose and character of the use, including whether such use is of a commercial nature or is for non-profit educational purposes;

(2) the nature of the copyrighted work;

(3) the amount and substantiality of the portion used in relation to the copyrighted work as a whole; and

(4) the effect of the use upon the potential market for or the value of the copyrighted work. ${ }^{98}$

The statute expressly provides that, among other fair uses, "the fair use of a copyrighted work . . . for purposes such as criticism, comment, [and] news reporting . . . is not an infringement of copyright." In addition, the drafters of the new copyright statute recognized as a fair use the "incidental and fortuitous reproduction, in a newsreel or broadcast, of a work located in the scene of an event being reported."100 While copyright courts generally have limited the fair use exception to copying for such noncommercial public interest purposes, ${ }^{101}$ in some cases even commercially motivated infringements

95. See Mazer v. Stein, 347 U.S. 201, 218 (1954).

96. Yankwich, supra note 91, at 214.

97. Judge Yankwich states that "whether there has been 'fair use' or not is a pragmatic question to be determined by the court, taking into consideration the particular circumstances of each case." Yankwich, supra note 91, at 205. He cites the following "general criteria" that have been examined in copyright infringement cases: "the value of the part appropriated; its relative value to each of the works in controversy; the purpose it serves in each; how far the copied matter will tend to supersede the original or interfere with its sale; and other considerations." "Id. (quoting Carr v. National Capital Press, Inc., 71 F.2d 220, 220 (D.C. Cir. 1934)).

98. 17 U.S.C. app. $§ 107$ (1976). The new copyright statute, 17 U.S.C. app. $\S \S 101-801$ (1976), went into effect on January 1, 1978.

99. 17 U.S.C. app. § 107 (1976).

100. H.R. REP. No. 94-1476, 94th Cong., 2d Sess. 65 (1976) (quoting U.S. Register of CoPYRIGHT, REPORT OF THE REgISTER OF COPYRIGHTS ON THE GENERAI REVISION OF THE U.S. CopYright LAW 24 (1961)).

101. See, e.g., Chicago Record-Herald Co. v. Tribune Ass'n, 275 F. 797 (7th Cir. 1921); Henry Holt \& Co. v. Liggett \& Myers Tobacco Co., 23 F. Supp. 302 (E.D. Pa. 1938); Goldstein 1012-13. 
have been excused as fair uses. ${ }^{102}$

The amount of material infringed is considered both quantitatively and qualitatively in a fair use analysis, with the relative weight given to this and other factors being dependent upon the particular circumstances of each case. Thus, the copying for commercial purposes of a relatively small amount of copyrighted material may be actionable when the infringing use significantly diminishes the value of the original work. ${ }^{103}$ Conversely, when the copying of an entire work advances public knowledge without causing economic injury to the copyright owner the use may be deemed fair. ${ }^{104}$ In general, therefore, an infringement will not be excused when the copying of a protected work causes economic harm to the copyright owner. ${ }^{105}$ This general rule is predicated on the policy of the copyright clause, which is aimed at promoting the public interest by protecting the economic incentive of authors. ${ }^{106}$

Recently, however, some courts and scholars have suggested that the fair use privilege is a public interest standard mandated not by the copyright clause, but by the first amendment. ${ }^{107}$ According to this view, the first amendment protects the public's "right of reasonable access to copyrighted material against a monopolistic construction of the statutory copyright privilege." 108 This protection is required, it is suggested, to serve the public's first amendment right to be exposed to a variety of creative, scientific and political expression-exposure that is deemed a prerequisite to the formation of educated and independent political judgments. ${ }^{109}$ To the extent that copyright permits the withholding of expression, or the restriction of its dissemination, the public's first amendment "right to hear, to read, and to view may . . . be

102. See, e.g., Rosemont Enterprises, Inc. v. Random House, Inc., 366 F.2d 303 (2d Cir. 1966), cert. denied, 385 U.S. 1009 (1967); Time, Inc. v. Bernard Geis Assocs., 293 F. Supp. 130 (S.D.N.Y. 1968).

103. See, e.g., Henry Holt \& Co. v. Liggett \& Myers Tobacco Co., 23 F. Supp. 302 (E.D. Pa. 1938). In Holt, a tobacco company used only a few sentences of the plaintiff's scientific work on the human voice in its cigarette advertising pamphlet. The court found that such a commercial use of a scientific work significantly diminished its value for the copyright owner. Id. at 304 .

104. See Williams \& Wilkins Co. v. United States, 487 F.2d 1345 (Ct. Cl.), affd, 420 U.S. 376 (1973) (library photocopying).

105. Professor Nimmer states that the decisions dealing with fair use can best be explained by looking to the central question of whether the defendant's work tends to diminish or prejudice the potential sale of the plaintiff's work, although this is not always the stated rationale. $3 \mathrm{M}$. NIMMER $\S 13.05[\mathrm{~A}][4]$.

106. See text accompanying notes $93-95$ supra.

107. See, e.g., Rosemont Enterprises, Inc. v. Random House, Inc., 366 F.2d 303 (2d Cir. 1966), cert. denied, 385 U.S. 1009 (1967); Goldstein; Rosenfield, supra note 91.

108. Rosenfield, supra note 91, at 794.

109. Goldstein 989 . 
sharply curtailed." 110 Consequently, these authorities suggest, the constitutional validity of copyright itself is questionable in the absence of a first amendment fair use privilege to infringe copyrights in the public interest.

Professor Nimmer, who was perhaps the first to recognize the presence of a conflict between the first amendment and copyright, ${ }^{111}$ draws a distinction between the statutory fair use exception grounded in the policy of the copyright clause and the first amendment privilege to infringe. ${ }^{112}$ In most cases where a public interest defense is raised, he would apply a nonconstitutional fair use analysis to determine whether the copying of an author's original expression diminished the value of the original work. Where the infringement of expression was substan-

110. Id.

111. See Nimmer, Does Copyright Abridge the First Amendment Guarantees of Free Speech and Press?, 17 U.C.L.A. L. Rev. 1180 (1970). Nimmer states that a "largely ignored paradox" is to be found in the coexistence of the first amendment, which commands that "Congress shall make no law . . . abridging the freedom of speech, or of the press," with the federal copyright statute, which forbids expression when it takes the form of an unauthorized use of copyrighted material. Id. 1181. Although the Supreme Court has not yet considered a case challenging the federal copyright statute on first amendment grounds, Nimmer views such a challenge as inevitable. Id. 1185-86. He believes, however, that copyright ultimately will be held constitutional because it protects only expression and not ideas themselves. By permitting the free use of ideas, he suggests, copyright does not detract from the free public discussion that the first amendment was designed to promote. Id. 1189. In a footnote to its opinion in Zacchini the Court indicated its agreement with Nimmer's analysis. 433 U.S. at 577 n.13.

112. A distinction between the two privileges was made in Triangle Publications, Inc. v. Knight-Ridder Newspapers, Inc., 445 F. Supp. 875 (S.D. Fla. 1978), where the district court ruled that the defendant's use of copyrighted material was not excusable under the fair use doctrine, but excused the use on first amendment grounds. The case involved a television commercial designed to promote the sale of the defendant's Sunday newspaper which contained a weekly television magazine supplement. The commercial featured an actor who held up a copy of the plaintiffs $T V$ Guide magazine while urging viewers to buy the defendant's publication instead. The plaintiff sought to enjoin further broadcasts of the commercial on the ground that it infringed its exclusive right, under section 106 of the Copyright Act, to publicly display its copyrighted magazine cover.

After finding that the cover of $T V$ Guide was protected by the plaintiffs copyright in the magazine, $i d$. at 879 , the court ruled that the commercial nature of the defendant's use precluded a finding of fair use. Turning next to a consideration of the defendant's first amendment claim the court observed that

[w] hen the Copyright Act and the First Amendment both seek the same objective, their future coexistence is easily assured. However, when they operate at cross-purposes, the primacy of the First Amendment mandates that the Copyright Act be deprived of effectuation. Rather than strike down an entire act as overbroad in such a situation, the judiciary prefers to interpret such a statute as narrowly as needed to preserve it for the effectuation of those of its purposes deemed consistent with the Constitution.

Id. at 882. Relying on Bates v. State Bar of Ariz., 433 U.S. 350 (1977), the court found that the use of the Copyright Act to enjoin the publication of the comparative commercial advertising at issue in Triangle would violate the first amendment guarantee of protection for commercial speech. Id. at 882-83. To avoid a first amendment conflict, the court denied the injunction, ruling that section 106 of the Copyright Act was not intended to protect copyright owners from "the disadvantage which arises from the perceived commercial superiority of a [competing] product ...."Id. at 883 . 
tial enough to harm the author's economic interests Nimmer would find that the use was not a fair one, in spite of the public interest claim. This result normally would not conflict with the first amendment, he explains, because of the idea/expression dichotomy: copyright protects an author's original expression, but the ideas contained in copyrighted material may be freely copied by anyone and disseminated to the public. $^{113}$

Nimmer recognizes, however, that with respect to certain copyrighted matter-usually graphic works-the idea/expression dichotomy is conceptually invalid because the author's ideas cannot be separated from his original expression without some sacrifice of the essential meaning and impact of the work. In cases involving works of this kind, he would apply a first amendment analysis that balances the economic interests of the copyright owner against the public's need for free access to the full meaning of the work. The use of this constitutional balancing test, Nimmer finds, also would most often result in a finding that the infringement was not privileged; the economic incentive policy of encouraging a broad range of creative and intellectual productivity usually would outweigh the public's immediate need for access to the particular work. In a few cases, however, Nimmer would find a compelling public need for access to the inextricably combined ideas and expression embodied in a copyrighted work. In these cases (which he would limit to those involving news photographs) he would find a copyright infringement excusable on first amendment grounds even if the economic value of the work to the author was diminished. ${ }^{114}$

\section{An Evaluation of the Court's Dichotomy}

Relying on a copyright analogy in Zacchini, Justice White reasoned that the protection of performers' exclusive publicity rights, by providing the economic incentive to invest time, talent and money in creating entertainment, would result in an increase in the total quantity of entertainment made available to the public. ${ }^{115}$ At the same time, he explained, the economic incentive provided by such protection ensures the broad dissemination of ideas by encouraging "the production of works of benefit to the public."116 Thus, he found, the question in Zacchini was not, as in defamation and privacy cases, whether a state may legitimately inhibit certain publications, but simply "who gets to do the publishing."117 In view of these considerations, the Court held

113. I M. NIMMER § 1.10[D]. The judicially created idea/expression distinction has been codified in the new copyright statute. 17 U.S.C. app. § 102(b) (1976).

114. $1 \mathrm{M}$. NIMMER $\S \S 1.10[\mathrm{C}], 1.10[\mathrm{D}]$.

115. 433 U.S. at 576.

116. Id. at 577.

117. Id. at 573. 
that while the press is free to report the "newsworthy facts" about a performance of interest to the public, "the First and Fourteenth Amendments do not immunize the media when they broadcast a performer's entire-act without his consent." 18

The Court's conception of Zacchini's publicity right as a form of state copyright protection arguably justifies a distinction drawn between performance infringement, on the one hand, and both the defamation/privacy torts and the traditional right of publicity on the other. ${ }^{19}$ As Justice White's opinion implies, state law protection of individuals' reputations and sensibilities has the immediate effect of inhibiting the publication of speech without producing any compensatory public benefit over the long term. ${ }^{120}$ Consequently, the media must continue to enjoy a significant measure of immunity from liability for defamation and privacy damages to ensure the free dissemination of news. A similar conflict with the public interest may inhere in the traditional right of publicity, since state law protection of the commercial value of a celebrity's name, likeness or personality serves primarily to enhance individual property rights. Because this protection also inhibits expression without serving at the same time to promote longterm first amendment concerns, a similarly broad public interest privilege arguably is required in such cases. ${ }^{121}$ The Court's double standard of protection for media infringements ${ }^{122}$ therefore would be difficult to justify if it were predicated solely upon a distinction between the individual economic interest protected by the right of publicity and the individual interests served by state defamation and privacy law. However, in the case of performance infringements a lesser standard of media protection can be justified on another ground.

118. Id. at 575 .

119. In addition to the "economic incentive" distinction, see text accompanying note 82 supra, the Court distinguished Zacchini on another ground:

[I]n this case, Ohio has recognized what may be the strongest case for a "right of publicity"-involving not the appropriation of an entertainer's reputation to enhance the attractiveness of a commercial product, but the appropriation of the very activity by which the entertainer acquired his reputation in the first place.

433 U.S. at 576.

120. See id. at 573.

121. The protection of a celebrity's economic incentive to exploit his name or likeness arguably serves only individual commercial interests and not a societal value. No first amendment benefit is achieved when a state encourages celebrities to lend their names and faces to the promotion of commercial products. However, the remedy provided by the traditional right of publicity occasionally may promote first amendment values. For example, in those cases where a name or likeness has been misappropriated to advertise or endorse a commercial product, the remedy provided by the right of publicity may guard against the dissemination of false and misleading advertising. In such cases, however, the public interest privilege is inapplicable. See note 73 supra and accompanying text.

122. See text accompanying notes $17-18$ supra. 
The right of publicity in performances is analytically distinct from the traditional right of publicity in names, likenesses and personalities. As the Zacchini Court suggested, economic protection for performers will, in the long run, increase the amount of entertainment available for public consumption. Consequently, the exclusive right of publicity in performances normally promotes the public's first amendment interests. No equivalent first amendment purpose is achieved, however, when a state provides celebrities with an economic incentive to commercially exploit their names, likenesses and personalities. Therefore, it is the public interest-promoting "copyright" purpose underlying the performer's exclusive publicity right ${ }^{123}$ that alone justifies a lesser standard of media protection when a performance is infringed. Nevertheless, while a broad media privilege to infringe newsworthy performances may not be required by the first amendment, the Court's "entire act" standard fails to recognize the inherent conflict between the right of publicity in performances and the first amendment. ${ }^{124}$ This conflict is revealed through an extension of the Court's own copyright analogy.

Despite disagreement among courts and scholars concerning the extent to which the first amendment limits copyright, all agree that at some point copyright comes into conflict with the first amendment. ${ }^{125}$

123. See text accompanying note 82 supra.

124. Given the unique circumstances of the Zacchini case, the Court's denial of a news privilege in that case seems justified. See text accompanying notes 151-55 infra. The "entire act" test, however, seems to have resulted from the Court's undue reliance on the fact that Zacchini's income was derived solely from his human cannonball act. Indeed, the Court expressly noted that by enabling viewers to see a free performance of the entire act the broadcaster's infringement went "to the heart of [Zacchini's] ability to earn a living as an entertainer." 433 U.S. at 576. When other individual interests are infringed, however, harm to the individual's ability to earn a living is not relevant to the question whether the infringement was privileged. In copyright law, for example, whether or not the infringed work is the sole source of the author's livelihood is irrelevant to fair use inquiry. See text accompanying notes 97-106 supra. Similarly, some celebrities' incomes are derived solely from commercial exploitation of their names or faces. The face of a famous photographic model, for example, might lose commercial value if it received excessive media exposure. Although a diminution of the value of the model's face also would go "to the heart of [his] ability to earn a living," all news uses of his photograph are nonetheless privileged. See text accompanying note 70 supra. Moreover, the reputational harm that the common law of defamation sought to redress was, at least in part, an economic interest that in many cases "went to the heart of [a plaintiff's] ability to eam a living." See W. PROSSER, THE LAW OF TORTs § 112, at 757 (4th ed. 1971). Nonetheless, the Court has firmly established that a state's legitimate interest in protecting its public figure citizens from reputational harm, including such harm that adversely affects their earning ability, is insufficient to overcome the media defense of first amendment privilege absent proof of knowing or reckless falsity. See text accompanying notes 59-60 supra.

125. See generally Rosemont Enterprises, Inc. v. Random House, Inc., 366 F.2d 303 (2d Cir. 1966), cert. denied, 385 U.S. 1009 (1967); Triangle Publications, Inc. v. Knight-Ridder Newspapers, Inc., 445 F. Supp. 875 (S.D. Fla. 1978); Time, Inc. v. Bernard Geis Assocs., 293 F. Supp. 130 (S.D.N.Y. 1968); Goldstein; Nimmer, supra note 111; Patterson, Private Copyright and Public 
Through judicial application of the idea/expression distinction, however, the copyright owner's economic interests may in most cases be fully protected without significant harm to the public's right of access to information. ${ }^{126}$ But this is not because public access to an author's expression as well as to his ideas is not required by the first amendment; rather, the idea/expression dichotomy is merely a temporary compromise designed to accommodate both the individual and the societal interests at stake in a copyright infringement case. ${ }^{127}$ The limited duration of statutory copyright protection ${ }^{128}$ is itself evidence of this compromise. The durational limit reflects the principle that once there is no longer an economic incentive present to justify a monopoly on expression, the first amendment requires that an author's expression as well as his ideas be made freely available to the public. ${ }^{129}$ Moreover, even during the term of a copyright a compelling need for immediate public access to copyrighted expression can outweigh the longterm public benefit that is expected to result from copyright protection. In such cases, courts have excused infringements of expression on public interest grounds regardless of the amount of copyrighted material infringed. ${ }^{130}$

Like a copyrightable fixed work, a live performance embodies both an idea and its expression. Thus, it can readily be conceptualized as a "work" capable of protection by the exclusive quasi-copyright ${ }^{131}$ recognized by the Zacchini Court. As in copyright, the underlying idea of such a protected work may be freely used by others. Therefore, the Court found, the television station was free to verbally describe Zacchini's act and to "stage ... or film ... its own 'human cannonball' act," ${ }^{\prime 132}$ even if to do so would require copying the idea of the act from Zacchini. With respect to certain works of this kind, however, the first amendment will require unrestricted access to more than

Communication: Free Speech Endangered, 28 VAND. L. REV. 1161 (1975); Rosenfield, supra note 91.

126. See, e.g., Walt Disney Productions v. Air Pirates, 345 F. Supp. 108 (N.D. Cal. 1972).

127. See Nimmer, supra note 111 , at 1192.

128. See 17 U.S.C. app. $§ 302$ (a) (1976): "IN GeNERAL.-Copyright in a work created on or after January 1, 1978, subsists from its creation and . . . endures for a term consisting of the life of the author and fifty years after the author's death."

129. Nimmer, supra note 111 , at $1193-95$. Nimmer suggested that the perpetual duration of common law copyright may have violated the first amendment because the economic incentive purpose disappears after the combined lifetimes of the author and his immediate descendants. Id. 1193.

130. E.g., Time, Inc. v. Bernard Geis Assocs., 293 F. Supp. 130 (S.D.N.Y. 1968). See I M. NIMMER $\$ 1.10[\mathrm{D}]$.

131. A live performance cannot be the subject of statutory copyright because it is not a work "fixed in any tangible medium of expression . . . ." 17 U.S.C. app. § 102(a) (1976).

132. 433 U.S. at 578 n.13. 
just the performer's "raw ideas."133

In some circumstances, certain information may be embodied only in a particular live performance and may meaningfully be conveyed only by the expression of that particular work itself. In such cases, the fixation and publication of a particular performance conveys information that is unavailable in any prior or subsequent live or filmed performance. Since there is no alternative means of access to the expression of such a work, a failure to allow dissemination of the work itself effectively prevents the dissemination of information. If the unique information contained in the work is relevant to the public interest, the public's immediate first amendment right of access to the work may outweigh the long-term need for new entertainment which is the public need served by the exclusive right of publicity in performances. Therefore, when an infringement of such a "newsworthy" performance is required to best serve the public interest, the media must enjoy a privilege to infringe.

Although a news privilege clearly is required in some cases, the Court's refusal to extend the Hill newsworthiness rationale ${ }^{134}$ to the facts of Zacchini may nonetheless have been justified. As the Court recognized, a standard that would privilege the media to infringe any "performance of interest to the public"135 eventually might harm the public interest by inhibiting the production of new entertainment while doing little to serve immediate first amendment values. Nevertheless, the Court's quantitative entire act standard is overinclusive because it precludes media immunity even in those cases where the public interest may be better served by the infringement of an entire performance. Moreover, in cases where a legitimate public interest defense is absent, a performer may still be denied a remedy for infringement of his act simply because he fails to meet the quantitative criterion of the Zacchini test. ${ }^{136}$ Therefore, because it fails adequately to accommodate either the first amendment or the quasi-copyright issues that may be presented in future performance infringement cases, the Zacchini entire-act standard is an inadequate legal test. In contrast, a qualita-

133. I M. NIMMER § 1.10[D].

134. See text accompanying notes 27-28 supra.

135. 433 U.S. at 576.

136. A slight modification of the actual facts in Zacchini demonstrates the underinclusiveness of the entire-act test. Had the television station shown only fourteen rather than fifteen seconds of Zacchini's performance the damage to the value of his act, if any, undoubtedly would have been the same. Nevertheless, the negative implication of the Court's holding is that the news infringement of less than an entire act is privileged by the first amendment. Under a traditional copyright analysis, however, the infringement of fourteen seconds of a fifteen second "work" normally would be deemed actionable, absent a finding of fair use. See text accompanying note 103 supra. 
tive "fair use" test for performance infringements would provide a more pragmatic and analytically consistent method of accommodating both of these interests. The next section will attempt to define the appropriate scope of a media privilege to infringe newsworthy performances and will propose a qualitative analysis that incorporates the privilege.

\section{A Newsworthiness Standard for Performance INFRINGEMENT CASES}

\section{A. The First Amendment Rationale for a Public Interest Exception.}

It is the position of this Note that the first amendment conflicts with the right of publicity in performances to a greater extent than it conflicts with copyright. ${ }^{137}$ Notwithstanding the Zacchini Court's apparent reliance on the notion that the idea and expression of Zacchini's act were independent and separable components, ${ }^{138}$ it may be argued that the idea/expression dichotomy is conceptually invalid when the work in question is a performance. As Professor Nimmer has observed, the first amendment justification for the idea/expression dichotomy in copyright "is not that ideas are useful without expression, but rather that while public enlightenment may require the copying of ideas from others, it remains perfectly possible for the speaker (or writer) who copies ideas from another, to supply his own expression of such ideas." 139 Thus, the economic incentive purpose of copyright outweighs the first amendment interests that are served by the copying of expression when an infringer could have substituted his own expression for that of the copyright owner. However, "in those special instances where the expression for a given idea may not be independently supplied by an idea copier," 140 the idea/expression dichotomy is no longer viable and a first amendment analysis must be applied.

The idea of an entertainer's act can rarely, if ever, be conveyed effectively by substituting expression in the form of a verbal description

137. The negative implications of both the Zacchini Court's reasoning and its entire-act rule suggest that the Court agrees with this proposition. For example, the Court was careful to note that Zacchini had not attempted to prevent dissemination of his act by seeking an injunction. 433 U.S. at 573. The Court's observation suggests that injunctive relief would be impermissible in a performance infringement case on first amendment grounds. However, a copyright infringement may be enjoined, 17 U.S.C. app. $§ 502$ (1976), without violating the first amendment. But see Goldstein 988.

In addition, the Court's provision of a purely quantitative entire-act test for performance infringement represents another departure from its copyright analogy. This departure suggests that the first amendment permits broader protection for copyrighted works than for performances.

138. See 433 U.S. at $573-74,578$ n.13.

139. $1 \mathrm{M}$. NIMMER \& 1.10[D].

140. Id. 
or an imitation for the performer's own expression. ${ }^{141}$ Therefore, since a performance cannot be separated into idea and expression components without a significant diminution of its meaning and impact, the idea/expression dichotomy cannot be applied in a principled manner to mitigate the conflict between the first amendment and a performer's exclusive publicity right. Since the idea/expression compromise is unavailable in this context, any protection of the exclusive publicity right in performances will necessarily conflict to some extent with the first amendment. Consequently, the question in a performance infringement case is not, as it is in copyright, whether both an infringement and a first amendment conflict could have been avoided by the use of the copier's own expression to convey another's ideas. Rather, the question is to what extent may an unavoidable first amendment conflict be tolerated in order to protect a performer's intellectual property interests from infringements. This question can be answered only through the case-by-case application of a first amendment analysis that balances the public benefit, if any, achieved by the infringing use of an act against the public benefit that may accrue from protecting a performer's economic incentive.

Such a qualitative first amendment analysis of performance infringements will necessarily bear some resemblance to the copyright fair use doctrine. Both analyses focus on the nature and circumstances of an unauthorized use of protected expression ${ }^{142}$ in order to determine whether the use should be excused or characterized as an actionable infringement. However, the performance infringement analysis must give greater deference to the first amendment since there is no affirmative grant of state authority equivalent to the policy expressed in the copyright clause ${ }^{143}$ that justifies the granting of an exclusive common law right in performances. Moreover, as was discussed above, exclusive protection for performers inherently conflicts with the first amendment to a greater extent than does copyright. Therefore, it may well be argued that the media privilege to infringe newsworthy performances should be broader than the copyright fair use exception, which generally is inapplicable where the copyright owner suffers economic

141. It has been said that "a work of art cannot be described; it can only be experienced." This is obviously true, as anyone who attempts to describe the "idea" of the Mona Lisa or of Michelangelo's Moses must realize. To the extent that a meaningful democratic dialogue depends upon access to graphic works generally . . . it must be said that little is contributed by the idea divorced from its expression.

Id. $\$ 1.10[\mathrm{C}][2]$.

142. The fair use doctrine is applied only where there has been copying of protected expression. See text accompanying note 113 supra.

143. U.S. CoNST. art. I, $\S 8$, cl. 8 . 
harm. ${ }^{144}$

On the other hand, the fact that a state's protection of performers' rights in their acts normally serves to promote first amendment concerns suggests that the newsworthiness privilege in performance infringement cases should be somewhat narrower than that enjoyed under New York Times and Hill. In order to narrow the privilege, however, the first amendment analysis must employ a "normative" rather than a "descriptive" definition of newsworthiness. ${ }^{145}$ Rather than granting the media a blanket privilege to make any "routine news" use ${ }^{146}$ of a performance, courts instead must determine whether the importance of the public interest in access to information required a particular performance infringement. This analysis would, of course, require courts to make value judgments which the Gertz Court thought were more appropriately made by editors than by judges. ${ }^{147}$ Nevertheless, as the Firestone decision illustrates, such normative decision making frequently is an unavoidable judicial task. ${ }^{148}$ Moreover, it is a task that courts have undertaken successfully in copyright infringement cases. ${ }^{149}$

\section{B. A Proposed Qualitative Analysis.}

A qualitative first amendment analysis of a performance infringement must balance the public interest served by the unauthorized broadcast of a protected work against the economic interests of the performer. In those cases where the long-term first amendment interest promoted by the economic incentive rationale is less weighty than the public's immediate need for access, the infringement should be excused regardless of the amount of material infringed. Where the economic

144. See note 105 supra and accompanying text.

145. Shortly after the Hill case was decided, Professor Kalven observed that

[n] ewsworthiness will almost certainly become a descriptive and not a normative term. In brief, the press will be the arbiters of it and the Court will be forced to yield to the argument that whatever the press prints is by virtue of that fact newsworthy. . . The upshot . . . is that the logic of New York Times and Hill taken together grants the press some measure of constitutional protection for anything the press thinks is a matter of public interest.

Kalven, supra note 28, at 284.

146. Justice Powell argued that Zacchini could not, "consistently with the First Amendment, complain of routine news reportage" after he chose to perform a newsworthy public act. 433 U.S. at 582 (Powell, J., dissenting).

147. See note 45 supra and accompanying text.

148. See note 45 supra.

149. See, e.g., Rosemont Enterprises, Inc. v. Random House, Inc., 366 F.2d 303 (2d Cir. 1966) (copying by biographer of another's work containing information about the life of Howard Hughes excused on public interest grounds); Time, Inc. v. Bernard Geis Assocs., 293 F. Supp. 130 (S.D.N.Y. 1968) (public interest excuses copying of film showing assassination of President Kennedy). 
incentive purpose is weightier, however, the infringement should be found actionable even where less than an entire-act has been infringed.

The question of public access to information is central to this first amendment inquiry. ${ }^{150}$ Like the television station's infringement of Zacchini's act, some performance infringements-although clearly "newsworthy" in a descriptive sense ${ }^{151}$-will do no more than provide the public with free access to entertainment it would otherwise have to pay for. All information that is contained in, and must be conveyed by, the performance itself can be obtained from any other performance of the same act. ${ }^{152}$ Thus, the public can be adequately informed by paying to see another, equally informative, performance. The existence of an alternative means of access to the act does not mean, however, that legal protection of a performer's economic interests in these circumstances does not conflict with the first amendment. On the contrary, prohibiting publication of the act by anyone but the performer clearly prevents the dissemination of entertainment (and the ideas it conveys) to the widest possible audience. This clash with the first amendment can be justified only if, on balance, the public interest will be better served by protecting the performer's economic incentive. It is at this point, then, that a court must make a normative evaluation of the newsworthiness of the infringed performance.

If it is found that dissemination of the information embodied in the performance can be suppressed to the extent necessary to protect the performer's economic incentive without adversely affecting free exchange in the "marketplace of ideas" 153 then the infringement should be deemed actionable. This finding would not require a judgment that pure entertainment does not "contribute . . . to the democratic dialogue." 154 The finding of "non-newsworthiness" would rest instead on a determination that the immediate contribution made by the information embodied in the work is outweighed by the long-term societal need

150. The Supreme Court has long recognized that the first amendment protects both the right to speak and the right of access to speech. Stanley v. Georgia, 394 U.S. 557 (1969); see, e.g., Red Lion Broadcasting Co. v. FCC, 395 U.S. 367, 390 (1969):

[It] is the purpose of the First Amendment to preserve an uninhibited marketplace of ideas ... rather than to countenance monopolization of that market ..... It is the right of the public to receive suitable access to social, political, esthetic, moral, and other ideas and experiences which is crucial here.

151. See note 145 supra.

152. Although information may be provided by the broadcaster along with free access to the protected work, the infringement of the work itself is not required to convey the information. For example, the news commentator could have informed the public that Zacchini was currently appearing at a local county fair without showing the film of Zacchini's act.

153. Red Lion Broadcasting Co. v. FCC, 395 U.S. 367, 390 (1969).

154. 1 M. NIMMER $\$ 1.10[\mathrm{C}][2]$. On the contrary, art (including entertainment) frequently is a very accurate barometer of social and political change. 
for exposure to various forms of creative activity. ${ }^{155}$ Even in these cases, however, the balance in favor of the long-term first amendment interest depends upon the presence of the economic incentive rationale. Consequently, where the infringement of a "non-newsworthy" performance has caused no actual economic harm ${ }^{156}$ to the performer, no first amendment interest is served by holding the broadcaster-infringer liable for damages. Conversely, where actual economic harm has resulted from a "non-newsworthy" infringement, the economic incentive rationale is equally weighty whether an entire act or less than an entire act has been infringed. ${ }^{157}$

While the use of a qualitative analysis would provide a remedy for some media infringements of "non-newsworthy" performances, the same analysis also would permit a finding of media immunity where an infringement of an act has occurred to serve the public interest. ${ }^{158}$ The entire-act standard, however, would prohibit the unauthorized use of an act, even if an infringement were required to report news involving a matter of significant public concern. This problem is illustrated by the following hypothetical case.

Suppose, for example, that a riot breaks out in the audience moments before the start of one of Zacchini's performances. A television reporter is present and films the event. Because the reporter is seated opposite the rioters the film captures Zacchini's entire fifteen-second flight. A local television station later broadcasts the film on the evening news, enabling millions of television viewers to see the entire human cannonball act. Zacchini sues in state court for infringement of his right of publicity. If the state court were to apply the entire-act test to these facts it would be compelled to find the television station liable for any damage to the value of Zacchini's act, simply because his en-

\footnotetext{
155. See id:
}

Admittedly, the democratic dialogue gains little from free access to graphic work "ideas" divorced from expression. But even were the speech value of free access to graphic work "expressions" to be weighed against the copyright value in encouraging the creation of such graphic works, the copyright interest would appear to prevail in most cases. . . . This is not to say that the visual impact of graphic works is totally without significance, but only that its weight, on balance, does not seem to equal the copyright interest that encourages the creation of graphic works.

156. Actual economic harm would include such elements as a reduction in box-office receipts, a reduction in bookings and the cancellation of contracts for future engagements. Compare the allowance of statutory damages for copyright infringement where actual damages cannot be proved. 17 U.S.C. app. § 504(c) (1976).

157. See note 136 supra.

158. Cf. Goldstein 988 (suggesting that the first amendment "requires that copyright infringement be excused if the subject matter of the infringed material is relevant to the public interest and the appropriator's use of the material independently advances the public interest"). 
tire-act was broadcast without consent. ${ }^{159}$ Under the qualitative analysis proposed here, however, the court would first evaluate the nature of the information conveyed by the infringement. If it determined that news of a riot is the kind of information that is essential to the "marketplace of ideas," the court next would ask whether a noninfringing news broadcast adequately could have conveyed news of the riot to the public. Since the only alternative available to the broadcaster would have been to give a verbal report of the riot, perhaps accompanied by still pictures, there is arguably no adequate substitute for the infringing news film. ${ }^{160}$ In the hypothetical case, therefore, the infringement would be excused-regardless of any economic injury to Zacchini-because the public's immediate need for complete information about a newsworthy event would outweigh its long-term need for entertainment.

In the hypothetical riot case, the infringing work-the news film-makes only an "incidental" use ${ }^{161}$ of the infringed work-Zacchini's act. The act itself conveys no newsworthy information; it merely is involved in a newsworthy event. In certain circumstances, however, the infringed work itself will be newsworthy. For example, if at the time of the filming of his act Zacchini had been injured when he landed in the net, that particular performance would have conveyed unique information that could not have been conveyed by any subsequent performance of his act. Under the proposed analysis, the television station would have been entitled by the first amendment to broadcast that entire act ${ }^{162}$ on the same grounds that justify the privilege in the riot case. As in the riot case, the only alternative available to the broadcaster would have been a verbal description of the accident. Again, resort to this alternative means of reporting a public event would have inadequately served the public's right of access to information. Since the long-term availability of entertainment would not have compensated for the suppression of information in this case, a court would have been justified in defining the performance as newsworthy.

159. See text accompanying note 118 supra. In a copyright infringement case an incidental news use would qualify as a fair use. See text accompanying note 100 supra.

160. See 433 U.S. at 580-81 (Powell, J., dissenting).

161. See note 159 supra.

162. It might be argued that this hypothetical case does not involve Zacchini's "entire" act on the ground that his usual entire act includes a safe landing. This possible distinction provides support for Justice Powell's observation that "in future cases involving different performances, ... difficulties in determining just what constitutes the 'entire act' are inevitable." 433 U.S. at 579 n.1 (Powell, J., dissenting). 


\section{Conclusion}

As the common law right of publicity continues to evolve, the burden will be on the states to ensure that their protection of performers' economic interests does not erode vital first amendment values. ${ }^{163}$ At the same time, however, the states should provide sufficient quasi-copyright protection to discourage performance infringements by the media when they do not serve to advance the public's first amendment interests. To best achieve this dual objective state courts require a flexible, qualitative standard that can be applied to a variety of performance infringement cases where the public interest is asserted as a defense.

The utility of the entire-act standard is clearly limited to the unique facts of the Zacchini case. As this Note has demonstrated, the mechanical application of the quantitative Zacchini standard in other cases may fail to deal adequately with either the quasi-copyright or the first amendment interests at stake. The application of a first amendment "fair use" test for news infringements of performances would, however, permit courts to evaluate both the intellectual property and the free speech aspects of each case.

The underlying newsworthiness concept of the New York Times and Hill line of precedent remains valid and applicable to the developing state law of intellectual property. While clarification of the concept arguably is necessary-one commentator has observed that although "the Court in Hill equated 'public interest' with 'newsworthiness,' it is only the former term which should endure for purposes of constitutional definition"164_-its essential usefulness is unchanged. Thus courts, relying on the underlying principle, may continue to privilege a much broader range of speech than that which concerns issues of "governing importance,"165 without being "forced to yield to the argument that whatever the press prints [or a television station broadcasts] is by virtue of that fact newsworthy."166

The necessary task of defining newsworthiness in a normative rather than a descriptive sense admittedly is a formidable one for courts to undertake. Nevertheless, as Justice Brennan observed in Gertz, the making of such normative judgments traditionally has been a function of courts in their role as "ultimate arbiters" of constitutional disputes. ${ }^{167}$ Justice Holmes long ago cautioned courts against avoiding

163. The Court stated that "the State of Ohio may as a matter of its own law privilege the press in the circumstances of this case . . " 433 U.S. at 578-79.

164. Goldstein 994.

165. See note 61 supra and accompanying text.

166. See note 145 supra.

167. 418 U.S. at 369 (Brennan, J., dissenting). 
the task of "weighing considerations of social advantage." "The duty is inevitable," he explained, "and the result of the often proclaimed judicial aversion to deal with such considerations is simply to leave the very ground and foundation of judgments inarticulate, and often unconscious . . . ."168

Phyllis Glass 